\title{
THE ENDURING LEGACY OF KAHLIL GIBRAN ${ }^{2}$
}

\author{
Suheil Bushrui \\ Email: sbushrui@umd.edu
}

\begin{abstract}
This year marks the 128th anniversary of the birth of Kahlil Gibran, who was born in 1883 , and died tragically at the early age of 48 . Few writers are in a position to speak as directly and resonantly to our times as Gibran was. A man of broad human sympathy for all creation, he held a passionate belief in the unity of mankind. His message of peace and reconciliation is more timely and more sorely needed than ever as relations between Christian, Muslim and Jew, between East and West, become ever more pressing matters of concern.

Keywords: Kahlil Gibran, East-West relations, Club of Rome, dialogue for conflict resolution, understanding between cultures and religions, spiritual revolution.
\end{abstract}

Título en español: El duradero legado de Kahlil Gibran.

Resumen: Este año marca el 128 aniversario del nacimiento de Kahlil Gibran, nacido en 1883 y fallecido trágicamente a la temprana edad de 48 años. Pocos escritores están en posición de dirigirse tan resonantemente a nuestros tiempos como él. Simpatizaba con toda la creación y creía apasionadamente en la unidad de la humanidad. Su mensaje de paz y reconciliación más oportuno y necesario que nunca en estos tiempos en que las relaciones entre cristianos, musulmanes y judíos, entre oriente y occidente se han convertido en grandes materias de preocupación.

Palabras clave: Kahlil Gibran, relaciones oriente-occidente, Club de Roma, diálogo para resolución de conflictos, entendimiento entre culturas y religiones, revolución espiritual.

We have come together on this day not to glorify a dead man, but rather to be glorified in a living one.

From Mikhail Naimy, Kahlil Gibran: A Biography

\author{
I shall live beyond death, and I shall sing in your ears \\ Even after the vast-sea wave carries me back \\ To the vast sea-depth. \\ I shall sit at your board though without a body, \\ And I shall go with you to your fields, a spirit invisible. \\ I shall come to you at your fireside, a guest unseen. \\ Death changes nothing but the masks that cover our faces. \\ The woodsman shall still be a woodsman, \\ The ploughman, a ploughman,
}

$* * *$

And he who sang his song to the wind shall sing it also to the moving spheres.

From Kahlil Gibran, The Garden of the Prophet.

Date of reception: 15 June 2011

Date of acceptance: 20 June 2011

2 (C) Copyright: Professor Suheil Bushrui.

Odisea, $\mathrm{n}^{\circ} 12$, ISSN 1578-3820, 2011, 7-14 
From Kahlil Gibran, The Garden of the ProphetTwenty-three years after the convulsion that was World War II, Aurelio Peccei founded the Club of Rome, which defined what it saw as the crucial problems facing humanity and the planet as the "world problematique." Specifically, the world problematique signifies the complex web of interdependent problems -political, economic, technological, environmental, psychological, and cultural- facing life on this planet. To its credit, the prestigious Club of Rome was one of the first global thinktanks to call attention to issues of sustainability and holistic thinking before such concepts became buzz words of the day.

What the Club of Rome defined on secular premises as the global, or world, problematique was, in a sense, what the great Lebanese poet, Kahlil Gibran, had already been aware of, decades earlier, on spiritual premises. That is, for Gibran, the challenges that face the future of the human race and life on this planet not only necessitate a global, holistic, and interdisciplinary approach but require, first and foremost, a spiritual revolution and a concomitant shift in human consciousness. Gibran's English and Arabic prose and poetry represent, in fact, an anguished cry to humanity to realign its lost balance with nature, to establish a universal code of human rights, to emancipate women, to build bridges of understanding between cultures and religions, to lessen the gap between the rich and the poor, and to curb all forms of exclusivism -whether ethnic, nationalistic, or religious- in the recognition of one common humanity and a shared spiritual heritage.

In assessing the prescience of Kahlil Gibran and his relevance today, it is useful to examine the Club of Rome's essential mission. ${ }^{3}$ In addition to identifying the world's problems and researching alternative solutions, the Club of Rome defines its mission as "The communication of such problems to the most important public and private decision-makers as well as to the general public." As far as the general public is concerned, Kahlil Gibran fulfilled that aim of the Club of Rome in a way that no other organization or individual has been able to achieve. He communicated to millions across the globe a culture of peace and inclusion. His most famous work, The Prophet, has been second only to the Bible in copies sold in America. Gibran's words became the life-breath of an American generation that had lost a sense of connection with the sacred through established religions and was engulfed in a crisis of conscience during the Vietnam War.

But Gibran's message was never restricted to that American generation. It was also a message for humanity at large. The core of that message, however, was a serious prescription for personal transformation, essentially spiritual in nature, demanding on the part of each individual profound changes in both thought and action, resulting in a unity of vision and ethic. The prescription was practical as much as it was idealistic. In fact, Gibran championed in The Prophet the interdependence of both reason and passion, the mind and the spirit:

...let your soul exalt your reason to the height of passion that it may sing;

And let it direct your passion with reason, that your passion may live through its own daily resurrection, and like the phoenix rise above its own ashes. ${ }^{4}$

Many of Gibran's proposals, simple as they may seem, are practical and implementable. Take, for example, this simple advice:

3 See the Club of Rome's website at http://www.clubofrome.org/about/mission.php.
4 Gibran (1998: 50-51)

Odisea, $n^{\circ} 12$, ISSN 1578-3820, 2011, 7-14 
My brothers, seek counsel of one another, for therein lies the way out of error and futile repentance. The wisdom of the many is your shield against tyranny. For when we turn to one another for counsel we reduce the number of our enemies. ${ }^{5}$

Negotiation, consultation and dialogue are the very foundation of conflict resolution in today's world and must be conducted at every level, whether individual, national or international. Another example is Gibran's recognition of the necessity for commercial activity in order for human beings to earn a living, distribute the fruits of their labors and provide for their families. But in place of an ethic of global capitalism, he proposes a more equitable and humane approach which leaves no one excluded or deprived. Thus his proposal seems to identify what globalization in material terms needs to achieve in order to succeed in creating a unified world-market in harmony and peace:

And before you leave the market place, see that no one has gone his way with empty hands.

For the master spirit of the earth shall not sleep peacefully upon the wind till the needs of the least of you are satisfied. ${ }^{6}$

While some have dismissed his impact - and with it the spiritual and cultural dimension of peace-building - Gibran has, in fact, been nothing less than a catalyst for change in human consciousness and a bridge between cultures and religions. It is therefore fitting that this commemoration of his life and achievements is dedicated to the British poet Kathleen Raine, whose unique vision equipped her to recognize his true worth at a time when his reputation had not yet developed as it deserved. The living legacy of Gibran is, in fact, now more apparent than ever in the pressing need for increased cultural exchange between the West and the Arab world. To be sure, Gibran - on behalf of both the East and the West - functioned as a cultural ambassador, bringing to each the wisdom of the other.

II

The exigencies of our time demand not only mutual understanding and generosity of spirit, but a critical evaluation and constant awareness of our own prejudices. When unexamined, these beliefs may possess the destructive potential of dogma to divide and alienate the peoples of the world. Gibran was equally unsparing and impartial in his condemnation of all these destructive forces, no matter what the belief system of those advocating their use.

Early in his writings, Gibran emphasized that the area of greatest import for our present age is the need to develop the consciousness of the oneness of humanity and the essential oneness of all religions. This became the central theme of Gibran's message which he expressed in the simplest and most immediate way in words that are unequivocal and sincere:

You are my brother and I love you.

I love you when you prostrate yourself in your

mosque, and

\footnotetext{
Gibran (1958: 66)

6 Gibran: (1998: 38)
} 
kneel in your church, and pray in your synagogue, You and I are sons of one faith - the Spirit. ${ }^{7}$

These lines encapsulate Gibran's strongest conviction, which inspired him to his greatest achievement: the leadership of a spiritual revolution which took place in America, the core of the materialistic, market-oriented culture of the West. Like Wordsworth, Gibran might have exclaimed:

The world is too much with us; late and soon,

Getting and spending, we lay waste our powers. ${ }^{8}$

His sense of exile in Boston and New York sharpened his awareness of the need for an alternative to the cultural chauvinism which was a relic of the colonial past and continued to taint extreme right- and left-wing ideologies equally, as did the First World War, with its brutal demonstration of the consequences of divisive and exclusive ideologies. Written five years after the First World War ended, The Prophet offers a universal message of spiritual healing for a torn and embittered world rent apart by the conflict not only between peoples but between faith and reason, between spiritual values and the demands of modern technology and scientific progress.

Gibran had drawn from the Arabic works of Ibn al-'Arabi, Ibn al-Farid and al-Ghazzali the concept of the Unity of Being, and with it a deeper vision of the nature of the universe. He was greatly inspired by the tradition of learning and spirituality in the culture of the Arab world which flourished at the crossroads of history. He found it to be a rich source of perennial philosophy expressed through a diverse range of literature and poetry, both religious and secular. This combination of practical and spiritual wisdom, known in Arabic literature as "the eternal wisdom," nourished his imagination from an early age. It was this tradition that taught him that within a unity of man and nature itself, there could be no place for internal strife and division at a spiritual level, and thus Gibran protested against the warring factions and conflicting interests which he saw as a threat to the light of unity.

"If we were to do away with the [non-essentials of the] various religions," Gibran once proposed, "we would find ourselves united and enjoying one great faith and religion, abounding in brotherhood."

And of that mysterious source of all faith he dared to write:

.... G God Who is good knows of no segregations amongst words or names, and were a God to deny His blessing to those who pursue a different path to eternity, then there is no human who should offer worship. ${ }^{10}$

His attempt at a reconciliation between Islam and Christianity and, according to The Prophet, the reconciliation of all the religious traditions of the world, makes him a forerunner

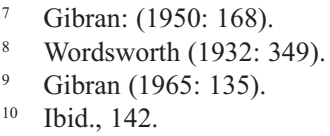


of an interfaith movement which was yet unborn. Ecumenical in every sense of the word, his statements with regard to faith, religion and acceptance of the other leave us in no doubt as to what his purpose was when he wrote an open letter addressed to all Muslims entitled "To the Muslims from a Christian poet." He announced:

I am a Christian and I am proud to be one, I also love the Arabian Prophet and exalt his name. I cherish the glory of Islam and fear its passing. I honor the Qur'an but I condemn those who use it as a means to thwart the endeavors of Muslims, I also deride those who use the Bible as a means to enslave Christians...

O Muslims, take my word: I am a Christian who has made a home for Jesus in one part of my being, and for Muhammad in another... ${ }^{11}$

Gibran's ardent belief in the power and efficacy of an all-embracing unity did not allow him to blur the distinctions between male and female, body and soul, reason and faith in an attempt to preach a facile message of superficial unity or to deny unmistakable distinctions. He sought instead to reconcile all opposites, create harmony and recognize the complementary values of each entity, and to enable, in the Quaker phrase, "that of God in every man" to be revealed through the inner light that guides each created being.

Such a vision of unity had permeated all he had done, and he had finally found this vision fully manifested in the person and the teachings of 'Abdu'l-Bahá, the son of the founder of the Bahá'í Faith. In 1912, 'Abdu'l-Bahá was conducting a speaking tour across North America, and that same year Gibran had the opportunity to meet him in New York City. The poet was deeply impressed by 'Abdu'l-Bahá's teachings and bearing, and in many ways, according to Gibran, he provided the template for Gibran's portrayal of Jesus in Jesus, the Son of Man. Gibran said of 'Abdu'l-Bahá, whose portrait he sketched: "For the first time I saw form noble enough to be a receptacle for the Holy Spirit."12

\section{III}

Gibran was a universalist, a true citizen of the world, and a poet who placed his voice at the service of all those unable to speak for themselves in defending human rights, the rights of women, and the earth itself at a time when the ecology movement was still far in the future. Had he been with us today he would have been grieved to observe the recent and belated recognition of the terrible consequences of global warming for the earth, its peoples and all the species which inhabit it. He would have reminded us that we hold this planet in trust for our children and their children's children, that our time on it is short but that the outcome of our actions will leave its traces for many generations to come. He would have called us to account for our deeds and to protect and cherish the earth as a heritage for posterity.

Closely associated with Gibran's lifelong and deep-rooted love of nature was his reverence for the capacity of women to nurture, nourish and protect. In this special area, he was far ahead of his times and his cultural background. It would be misleading to label Gibran a feminist in the unduly restrictive sense of the term; his concern encompassed humanity as a whole, but within it he had a particular care for the rights and wrongs of one class, whose sufferings he had witnessed at first hand, and whose qualities he had had

Published in Al-Funoon (1966: 37-38).

12 Honnold (1982: 158). 
every opportunity to appreciate. As he wrote, God gives to the spirits of both women and men "wings to soar aloft into the realms of love and freedom"13 and a faith which "makes us all brothers [and sisters] equal before the sun," 14 and to oppress women was thus a crime against God Himself, implying an attempt to thwart His purposes. In a letter written to May Ziadeh in 1928, Gibran described the central role women had in his life:

I am indebted for all that I call "I" to women, ever since I was an infant. Women opened the windows of my eyes and the doors of my spirit. Had it not been for the woman-mother, the woman-sister, and the woman-friend, I would have been sleeping among those who seek the tranquility of the world with their snoring. ${ }^{15}$

He specifically criticized the sufferings of women in an unjust and ruthless social system maintained by equally corrupt religious and political establishments. He called for a transformation in the traditional relationships between men and women, and expressed the importance that each should recognize the sanctity and integrity of the other.

\section{IV}

The question to ask at this point is why was it that Gibran's message - which was so clear, so immediate, so vital for our times and expressed in such lyrical, powerful and persuasive language -was so slow to gain the recognition which it merited so richly? The answer may well be in that very accessibility, and the simplicity and directness with which he addresses his readers. Nevertheless, the Penguin Press, in celebration of its $60^{\text {th }}$ anniversary in 1995 , named Gibran as one of the most important authors of the twentieth century and included him in the anniversary series in honor of those authors. This well-deserved act of homage indicates the growing understanding of his true significance. Few authors can be in the privileged position of having a work of theirs never go out of print from the date of its first publication. This is the case with Gibran's most famous book, The Prophet, first published in 1923. Its simple messages on such enduring and universal themes as love, marriage, work and death, were expressed in pithily direct aphorisms that transcended barriers of culture and nationality and made Gibran internationally known. His first work in English, The Madman, was published in 1918. From 1918 until his death, he wrote exclusively in English, a fact that assured him an extensive international audience receptive to his universal message. Academia, alarmed by the popularity of The Prophet in the 1960s, associated it with the Flower Children.

Moreover, in purely literary terms Gibran was swimming against the current. Although his adventurous use of form and language gave Arabic literature a new freshness, vigor and sense of direction, his English writings appeared at a time when the forces of Expressionism, Naturalism and Realism in the tradition of Upton Sinclair and Theodore Dreiser -both disillusioned and degraded by the experiences of the First World War- were strong in American drama, fiction and poetry. In this climate, Gibran's particular brand of Romanticism was unlikely to find ready acceptance in scholarly circles or among the literary avant-garde.

\footnotetext{
13 Gibran (1948: 121).

14 Ibid., 110.

15 Gibran (1959: 84).
} 
Nevertheless, poets such as the Irish AE (George Russell) and the American Robert Hillyer recognized his unique genius and the need for a new critical methodology to evaluate it, drawing from the disparate critical traditions of East and West without being shackled by the prejudices and limitations of either. More recently, two distinguished, major British poets have given Gibran's work a stamp of approval and authority as a major contribution to literature written in English. Kathleen Raine and Francis Warner both came to Beirut in 1983 to help celebrate and honor the $100^{\text {th }}$ anniversary of Gibran's birth. They both brought Gibran's message of hope and reconciliation to a Lebanon torn by conflict and war. Kathleen Raine not only defended Gibran's position, but emphasized his place in twentieth-century literature. In the foreword to Kahlil Gibran: Man and Poet (A New Biography) co-authored by Joe Jenkins and myself, she stated:

Communism and capitalism alike have believed that mankind could be fed on "bread alone" but once again the prophets of the ever-living spirit have shown that the "Word of God" is the necessary food of the soul. It is as if one mind had spoken through their several voices, none more eloquent or beautiful than the lonely voice of the Christian Lebanese Arab, Kahlil Gibran. ${ }^{16}$

$\mathrm{V}$

Perhaps Kahlil Gibran today has been confirmed as one of the most creative and controversial writers of the twentieth century. By the mid-1980s and early 1990s, over eight million copies of The Prophet had been sold. By all estimates, The Prophet without doubt is among the most widely read books of our time despite first appearing in an age when it was impossible to generate by intensive publicity the kind of sales which modern bestsellers enjoy. Today, Gibran's work is available in more than forty different languages including some vernaculars within the one language. This has enabled him to be read and appreciated in places as far apart as Tokyo, Beijing, Delhi, Manila, Nairobi, Rome, Paris, London and New York. In America, Gibran's achievement as an influential literary figure received dual confirmation in the academic and public spheres in the 1990s when the University of Maryland established the Kahlil Gibran Chair for Values and Peace Project under the auspices of the new Kahlil Gibran Professorship at the Center for Heritage Resource Studies, while the United States Government created a memorial garden in his honor in the heart of Washington, D.C. The first was an institutional decision by a major American university, ending years of unwarranted academic reluctance to include Gibran in the curriculum. The second was the result of a bill passed by Congress and the House of Representatives, followed by a special commemoration ceremony in May 1991, over which the then-President of the United States of America presided. Gibran must surely be the only immigrant poet ever to have been accorded such academic and national recognition.

\section{VI}

Many poets, from Horace to Pushkin, have described the imperishable heritage which they were to leave mankind in terms of a lofty monument more enduring than bronze, but Gibran's own words with regard to the timeless quality of the spirit's legacy are closer to the simple vision of the English poet John Clare:

\footnotetext{
16 Kathleen Raine (1998: vii).
} 
In every language upon earth, On every shore, o'er every sea, I gave my name immortal birth And kept my spirit with the free. ${ }^{17}$

Truly this prefigures and testifies to the truth of Kahlil Gibran's own prophetic statement:

I came to be for all and in all.

That which alone I do today shall be proclaimed before the people in days to come.

And what I now say with one tongue, tomorrow will say with many. ${ }^{18}$

\section{REFERENCES}

Al-Funoon. 1966 quoted in Habib Masoud (ed.), Jubran Hayyan wa Mayyitan. Beirut: Rihani Publications.

Clare, John. 1966 quoted by John Press in The Fire and the Fountain: An Essay on Poetry. London: Methuen.

Club of Rome's website at http://www.clubofrome.org/about/mission.php

GiBRAn, KaHLIL. 1948. Spirits Rebellious, translated from the Arabic by H. M. Nahmad. (New York: Alfred A. Knopf, Inc.

Gibran, Kahlil. 1950. A Tear and a Smile, translated from the Arabic by H. M. Nahmad. London: Heinemann.

Gibran, KahliL. 1958 The Voice of the Master, translated from the Arabic by Anthony R. Ferris. London: Heinemann.

GiBRAN, KAHLIL. 1959. A Self-Portrait, translated from the Arabic and edited by Anthony R. Ferris. New York: The Citadel Press.

Gibran, Kahlil. 1965. "Iram, City of Lofty Pillars" in A Treasury of Kahlil Gibran, edited by Martin L. Wolf and translated from the Arabic by Anthony Rizcallah Ferris. New York: The Citadel Press.

Gibran, Kahlil 1998. The Prophet. New York: Alfred A. Knopf, Inc.

Honnold, A. (ed.). 1982. Vignettes from the Life of 'Abdu'l-Bahá. Oxford: George Ronald.

Raine, KathleEn. 1998. "Foreword" in Suheil Bushrui and Joe Jenkins, Kahlil Gibran: Man and Poet (A New Biography). Oxford: Oneworld.

Wordsworth, William. 1932, in The Complete Poetical Works of William Wordsworth, edited by Andrew J. George. Boston: Houghton Mifflin Co.

17 Clare (1966: 6).

18 Gibran (1950: 172).

Odisea, $n^{\circ} 12$, ISSN 1578-3820, 2011, 7-14 